University of East London Institutional Repository: http://roar.uel.ac.uk

This paper is made available online in accordance with publisher policies. Please scroll down to view the document itself. Please refer to the repository record for this item and our policy information available from the repository home page for further information.

To see the final version of this paper please visit the publisher's website.

Access to the published version may require a subscription.

Author(s): Rustin, Michael

Article Title: The Making of Political Identity: Edward Thompson and William Cobbett Year of publication: 2003

Citation: Rustin, M. (2003) 'The Making of Political Identity: Edward Thompson and William Cobbett', Soundings, 24, July 2003 pp131-152

Link to published version:

http://www.ingentaconnect.com/content/lwish/sou/2003/00000024/00000001/art0001 3

DOI: (not stated)

Publisher statement: http://www.lwbooks.co.uk/permissions.html

Information on how to cite items within roar@uel:

http://www.uel.ac.uk/roar/openaccess.htm\#Citing 
Published in Soundings 24, 1321-152, Autumn 2003

\section{The Making of Political Identity: Edward Thompson and William Cobbett.}

\section{Michael Rustin}

William Cobbett, in 1831, wrote an open letter to the Yeoman Militia who had been called out to suppress the Captain Swing disturbances in the countryside. Cobbett argued that these crimes could not be blamed on the 'the vicious disposition of the working people.' ... No, this cannot be the cause,' he wrote. 'The people are of the same make and nature that they always were...There must therefore be some other cause or causes to produce these dreadful acts in a people the most just, the most good natured, the most patient in the world.....'The great and general cause,' Cobbett continued, is the extreme poverty of the working people; or, in other words, the starving state in which they are. That Bible, which they had been taught to read, as the means of saving their souls, tells them them, from one end to the other, that their bodies are also not to be left to perish for want, while the land abounds with plenty, , and that plenty arising too, from their own labour.'

Cobbett was courageous in coming to the defence of those driven to arson and other violent acts of protest.

Twopenny Trash, 1 November 1831, Pp. 97-98.

Here is Cobbett, two months later, addressing more prosperous people on the great fear about these same disturbances:

To the Yeoman Cavalry:

On the Fires. 
'I cannot call you friends, and I will not call you gentlemen. This plague of the country is now raging with greater fury than ever, and I think it proper to address you on the subject. You are called yeoman cavalry; though perhaps more than half of you are loan-mongers, tax-gatherers, dead-weight people, stock-jobbers, shagbag attorneys, bailiffs (mostly Scotch), toad-eating shopkeepers, who are ready to perform military duty towards the "lower orders" in order at once to give evidence of your gentility, and to show your gratitude towards your rich customers for their paying your long bills without scruple. A very great part of you come in under one or the other part of this description; but to those of you who are farmers; that is to say who have land in your occupation; and who grow corn, and rear cattle, and who have barns, ricks and other things, liable to be set fire to; to you only do I address myself upon this occasion, being well aware that my arguments would produce no impression whatever upon your comrades above-mentioned. First of all, call the roll of your corps over, and see how many of them there are who are not interested in the taxes and the tithes, either immediately or through their relations, landlords or somebody else. When you have called the roll, and have separated yourself from the rest, get into a plain room, pull off your hairy caps, your parti-coloured jackets and your Wellington-boots; put on your own Christian-like clothes, your high shoes well-nailed; and then pick out someone with a good strong voice to read to you that which I am about to write.'

Twopenny Trash, January 1 1832, P. 145-46.

In 'Sir, Writing by Candlelight', (New Society, 24 December $1970{ }^{1}$ ), Edward Thompson also addressed himself to the middle-classes in their role of guardians of law and order, though he is concerned with the construction of moral panic through the correspondence columns of The Times rather than with the volunteer militia.

Thompson introduces his polemic with a quotation, and then placed it amidst historical precedents which include those of the early 1800s. Nine years later, in 1979, the majority reaction to the disturbances of the 'Winter of Discontent' ushered in the Thatcher Governments. 
'Let the power workers dim the street lamps, or even plunge whole districts into utter darkness, the lights of righteousness and duty burn all the brighter from 10,000 darkened drawing-rooms in Chelsea or the Surrey Hills.

"Sir,

May I, writing by candlelight, express my total support for the government in their attempt to halt the unbelievably inflated wage claims now being made?

inquired one correspondent to The Times (12 December). Undoubtedly he may and will.

(Writing by Candlelight, P. 39)

Thompson is describing what 'an epistolary levée en masse' of the readers of The Times, though in passing he refers to the

'true, physical levées en masse of the bourgeoisie against the plebs (The Volunteers against the Jacobins in 1800 , the Yeomanry against the poor of Peterloo, the Specials against the Chartist 10 April, the debs and Oxbridge undergraduates against the General Strike.'

The Yeomanry referred to are the self-same forces against whom Cobbett was writing twelve years later. Thompson, like Cobbett, contrasts the lives of ordinary citizens to the fevered representations in the minds of the middle classes.

Thompson's version of everyday life and its needs is, however, a fully modern one:

'The grand lesson of the "emergency" was this; the intricate reciprocity of human needs and services - a reciprocity of which we are, every day, the beneficiaries. In our reified mental world we think we are dependent upon things. What other people do for us is mediated by inanimate objects; the switch, the water tap, the lavatory chain, the telephone receiver, the cheque through the post. That cheque is where 
the duties of the good bourgeois end. But let the switch, or the tap, the chain or the receiver fail, and then the bourgeois discovers - at once - enormous 'oughts' within the reciprocal flow.

But these 'oughts' are always the moral obligations of other people; the sewage workers ought not to kill fish, the dustmen ought not to encourage rats, the power workers ought not to imperil invalids, and - this week it will be - the postmen ought not to deny bronchitic old-age pensioners their Christmas parcels from grandchildren in Australia. Why, all these people owe a duty to the "community."

What the duty of the community is to these people is less firmly stated.'

$$
\text { (op. cit., P. 47.) }
$$

\section{$\underline{\text { Thompson and Cobbett }}$}

There are far more index references (59) to William Cobbett than to anyone else in The Making of the English Working Class, where Cobbett is also the subject of what is in effect a separate and generally admiring chapter (part II of chapter 16). He was a source whose method was in some ways very congenial to Edward Thompson. Cobbett's writing was always full of detail, was drawn from observation and experience, and was based on a deep and personal identification with the circumstances of the labouring people to whom he felt both an attachment and a moral responsibility ${ }^{2}$. The rural labourers and independent farmers of Cobbett's England became transmuted as subjects of political identification in Thompson's experience, and that of the British Communist tradition, into an urban working class, known and admired through their most articulate representatives through the Party and through adult education. The Making of the English Working Class of course describes the transformation of Cobbett's rural labourers into the urban working class of the nineteenth and early twentieth centuries. The essays in Customs in Common describe the erosion of a morally-regulated agricultural economy whose traditional responsibilities and decencies, as he saw them, Cobbett's life was devoted to 
defending. The game laws, which are one of the main subjects of Whigs and Hunters had also been an important issue for Cobbett, who defended the right of the people to take wild animals, and who attacked the barbarous punishments meted out to them. ${ }^{3}$ Thompson's insistence, in later controversies, on the virtues of empiricism had as its model not only the scientific empiricism of Darwin, or Marx, but also the writer's and journalist's empiricism of Cobbett, rooted in his experience, observations and feelings. Thompson writes of one passage of Cobbett:

'Everything here is solid, and related, not to a literary culture, but to commonly available experience.' (Making, Penguin ed., P. 823), and of another passage:

'...wherever he was, Cobbett always compelled his readers, by the immediacy of his vision, the confusion of reflection and description, the solidity of detail and the physical sense of place, to identify themselves with his own standpoint. And "standpoint" is the proper word, for Cobbett placed himself firmly in some physical setting - on his farm at Botley or on the road into Tenterden - and then led outwards from the evidence of his senses to his general conclusions.' (ibid, p. 827).

Here is Cobbett on the road to Tenterden:

'Coming through the village of BENENDEN, I heard a man, at my right, talking very loud about houses! houses! houses! It was a Methodist parson, in a house, close by the road side. I pulled up, and stood still, in the middle of the road, but looking, in silent soberness, into the window (which was open) of the room in which the preacher was at work. I believe my stopping rather disconcerted him; for he got into shocking repetition. 'Do you KNOW,' said he, laying great stress on the word KNOW: 'do you KNOW, that you have ready for you houses, houses I say; I say do you KNOW, do you KNOW that you have houses in the heavens not made with hands? Do you KNOW this from experience? Has the blessed Jesus told you so? And, on he went on to say, that if he had not, and did not, they would be damned. Some girls whom I saw in the room, plump and rosy as could be, did not seem to be at all daunted by these menaces; and indeed, they seemed to be thinking much 
more about getting houses for themselves in this world first; just to see a little before they entered, or endeavoured to enter, or even thought much about, those 'houses' ' of which the parson was speaking; houses with pig-styes and snug little gardens attached to them, together with all the other domestic and conjugal circumstances, these girls seemed to me to be preparing themselves for. The truth is, these fellows have no power on the minds of any but the miserable.' Rural Rides, Pp. 181-182..

Thompson of course shared Cobbett's abundant dislike of the Methodists.

Cobbett is certainly a strong representative, in Thompson's mind, of the 'empirical idiom' which he later defends in his great polemics first with Perry Anderson and Tom Nairn, then with Louis Althusser, distinguishing this habit of thought from the ideology of empiricism. Thompson's identification with Cobbett, his imaginative presence in the formation of Thompson's own political voice, seems to have been very deep. He said, after all that

'It was Cobbett who created this Radical intellectual culture, not because he offered the most original ideas, but in the sense that he found the tone, the style, and the arguments which could bring the weaver, the schoolmaster, and the shipwright, into a common discourse.' (ibid., P. 820).

There is no doubt that this was one of Thompson's aspirations as a political writer throughout his life, and one which he sometimes brought off. He wrote that 'Cobbett was the free-born Englishman incarnate.' (P. 824). There could hardly be higher praise from Thompson, though he is also objective and balanced in noting his limitations as a political leader.

What he found in Cobbett's writings, and which it seems to me had a great influence on his own identity as a writer and political figure, was a way of experiencing himself as a public person, that is to say a way of relating to events, to opponents, and to a democratic public. What he is able to learn from Cobbett was above all in the 
dimensions of identity.

What are the features of this identity? Well, in the first place, as Thompson points out, it had a personal voice, and the writing (of both Cobbett and Thompson) is often most effective when this 'voice' is most clearly established. Cobbett intended much of his writing to be read aloud, no doubt often to those who were unable to read him for themselves. One can often hear the forms of speech through his prose - George Spater, one of his recent biographers, points out that 'most of Cobbett's writing is the spoken word which has happened to find its way into print. ${ }^{4}$ Another biographer, lan Dyck, ${ }^{5}$ has pointed out that Rural Rides is among other things the report of the journey of a political organiser, giving speeches mainly to farmers in the towns that he visits, and put up for the night by different 'friends', personally known and unknown. Cobbett, though he is fairly discreet about it in Rural Rides, is not on the road merely to collect material for his writing. This is reminiscent of more modern political speaking tours, of which Thompson himself had several kinds of experience, in his Communist, New Left, and peace campaigning days.

Cobbett, writing his hundreds of thousands of words of journalism, ${ }^{6}$ turned the construction of this 'voice' into a considerable art. ${ }^{7}$ Much of his writing, in the Political Register, took the form of the 'address' - that is a communication from himself to some identified person or designated group of persons. Cobbett wrote these addresses in his own person, and is often highly self-referential. He can presume, as the writer and editor of a weekly publication, Cobbett's Political Register, that his readers remember some of what he written before, and that these public debates have their history. Rural Rides uses the format of a diary or travel memoir, and through the writerly device of his reported journey is able to hold together a variety of reflections and kinds of subject-matter - for example, political polemic, topographical reflection, and his continuing survey of the condition of the land - without awkwardness. He uses his eyes as he goes along, he encounters individuals whom can interrogate, his thoughts are provoked by names and reputations - for example of the owners of the land he crosses or passes by. But above all he has his ceaseless flow of observations - 
didactic, indignant, quizzical, reflective or appreciative of the beauty or comeliness of what he sees. It is in these personal ways, by establishing his presence as a witness or interlocutor, that Cobbett establishes his authority to speak for those without public voices.

'In quitting FRANT I descended into a country more wooded than that behind me. I asked a man whose fine woods those were that I pointed to, and I fairly gave a start, when he said, 'the MARQUIS CAMDEN'S.' Milton talks of the Leviathan in a way to make one draw in one's shoulders with fear; and I appeal to anyone, who has been at sea when a whale has come near the ship, whether he has not, at the first sight of this monster, made a short of involuntary movement, as if to get out of the way. Such was the movement that I now made. However, soon coming to myself, on I walked my horse by the side of my pedestrian informant. It is BAYHAM ABBEY that this great and awful sinecure placeman owns in this part of the country. Another great estate he owns near Sevenoaks. But here alone he spreads his length and breadth over more, they say, than ten or eleven thousand acres of land, great part which consists of oak-woods. But, indeed, what estates might be not purchase? Not much less than thirty years he held a place, a sinecure place, that yielded him about THIRTY THOUSAND POUNDS A-YEAR! At any rate he, according to Parliamentary accounts, has received, of public money, LITTLE SHORT OF A MILLION OF GUINEAS. These, at 30 guineas an acre, would buy thirty thousand acres of land. And, what did he have all this money for? Answer me that question, WILBERFORCE, you who called him a 'bright star', when he gave up a part of his enormous sinecure. He gave up all but the trifling sum of nearly three thousand pounds a-year! What a bright star! And when did her give it up? When the radicals had made the country ring with it. When his name was, by their means, getting into every mouth in the kingdom; when every radical speech and petition contained the name of CAMDEN. Then it was, and not till then, that this 'bright star,' let fall part of its 'brilliancy.' So that Wilberforce ought to have thanked the radicals, and not CAMDEN.' 


\section{Rural Rides, pp. 176-177.}

Cobbett was able through his writing to hold together different aspects of his relationship to his public. He can move in a single passage from the role of tribune and defender of the people against Old Corruption, to that of a kind of W.E.A. teacher of matters agricultural. For example, in the issue of his Twopenny Trash for April 1831, Cobbett writes an address to 'The Labourers of England.' He begins by reminding his readers about the fate of two labourers, Joseph and Robert Mason of Bullington (one of the 'little hard parishes' in the north of Hampshire) who had been 'transported for life, having been condemned to death'. These, wrote Cobbett, were 'perfectly sober and honest men', men of whom it 'was proved they read Cobbett's Register and Cobbett's History of the Protestant Reformation', and who had been found guilty of riot against the conditions of the 'hard parishes'. Cobbett felt a particular responsibility for the fate of these two men, since he thought that they had been sentenced severely and unjustly because of this suspected association with his campaigns. Cobbett goes on to welcome the impending Parliamentary Reform, whilst pleading with his readers not to expect too much of it too soon. But he concludes his address with an intense and rather inspiring piece of instruction concerning the cultivation of a dwarf form of Indian Corn which he says was brought into England by his eldest son:

'Now, my friends, this bacon being the standard with me, I am about to give you instructions how to get more bacon that you would not be able to get without those instructions. I am not conceited enough to think that I can tell you anything useful concerning those things which you have been accustomed to from your infancy; but I am going to tell you about something that you cannot know anything about. I am going to tell you how to get the means of fatting a pig of ten score, without peas, beans, barley or oats....

\section{Instructions to Labourers for Raising Cobbett's Corn.}

I will first describe this corn to you. It is that which is sometimes called corn; and 
sometimes people call it Indian wheat. It is that sort of corn which the disciples ate as they were going up to Jerusalem on the Sabbath day. They gathered it in the fields as they went along, and ate it green, they being "an hungered", for which, you know, they were reproved by the Pharisees. I have written a treatise on this corn, in a book which I sell for two and sixpence, giving a minute account of the qualities, the culture, the harvesting, and the various uses of this corn; but I shall here confine myself to what is necessary for a labourer to know about it, so that he may be induced to raise, and may be enabled to raise enough of it in his garden to fat a pig of ten score.'

Twopenny Trash, 1831, PP. 229 - 229.

Modern adult education lecturers, of which of course Thompson was once one, might wish sometimes that what they had to teach was as immediately useful to their pupils as this. Cobbett addresses his readers at the end of this lesson, acknowledging the strangely public and impersonal nature of what is other respects feels to him like a relationship between persons:

'You must be quite sensible that I cannot have any motive but your good in giving you this advice, other than the delight that I take and the pleasure which I derive from doing that good. You are all personally unknown to me: in all human probability not one man in a thousand will ever see me. You have no more power to show your gratitude to me than you have to cause me to live for a hundred years.' (In fact, Cobbett is by now 68, and lived only for four more years). 'I do not desire that you should deem this a favour received from me. The thing is worth your trying at any rate. (P. 233).

After this reflection on the impersonal nature of mass communication, Cobbett concludes in practical mode, listing fifty gentlemen to whom he has promised to send parcels of corn seed, to pass on to such labourers as they may choose, together with his little manual of instruction. Among those named is the widow Mason, the mother of the two transported labourers he has mentioned earlier. 
Cobbett makes frequent reference in his writings to the individual victims of government and judicial oppression, those who have been unjustly hanged or transported, to ensure that they are not forgotten. His imprisonment in Newgate for two years from in was for his 'seditious' protests against the flogging of allegedly mutinous soldiers (he had himself been a soldier

in Canada from 1785 to 1791). His solidarity with the victims of the oppressive judicial system was an important basis for the people's trust in him. His practice of telling the stories in print of these individual sufferers from injustice pioneers the activity of later radical journalists in exposing individual abuses of the law.

Cobbett's practice of identifying or naming individuals who are to stand as representatives of his larger audience (an important aspect of his writing in Rural Rides) puts one in mind of the numerous techniques used by the mass media today to represent public events in meaningful individual terms. These methods include television reportage, vox pop interviews, 'question times' with studio audiences, and documentary drama, and of course the degree to which they provide a genuine voice for people is variable. However, the problem of making public events meaningful to audiences in personal terms is inseparable from mass democracy and mass communication. Cobbett was a pioneer of many forms of popular writing - the open letter to a public figure (the opening step in an imaginary dialogue), the political column (with its identifiable voice or style), the manual of popular instruction, the travel memoir, the popular history.

As we have seen, he could combine these genres. His English Grammar, for example, used its examples to provide some political amusement well as instruction in language, as in the following, quoted by George Spater, where Cobbett refers to nouns of number:

Such as Mob, Parliament, Rabble, House of Commons, Regiment, Court of King's Bench, Den of Thieves, and the like.'

and, in relation to the Queen Caroline quarrel: 
The Queen defies the tyrants; the Queen defied the tyrants; the Queen will defy the tyrants. 8

His History of the Protestant Reformation was among other things a defence of medieval Catholic ideas of moral responsibility for the poor, and an account of the origins of contemporary Whig jobbery in the expropriation of the monasteries. What held this prodigious variety of writings together was Cobbett's strong sense of self and voice. As Thompson pointed out in The Making this style of personalisation which worked so well for Cobbett provided rather an unfortunate model for his radical successors, encouraging divisiveness and egotism when solidarity and cooperation were needed. Whereas it was perhaps only possible for a radical public to be initially gathered together by a powerful and self-confident personality such as Cobbett, ${ }^{9}$ its next stage of development required more collective approaches which as Thompson pointed out were somewhat alien to Cobbett himself. ${ }^{10}$

Cobbett's 'addresses' in the Political Register and the Twopenny Trash (he enjoyed turning denigration by the governing class, such as 'The Twopenny Trash' into a badge of honour) were to two distinct kinds of subject. One was the people or an identified body of them - for example, 'To the Journeymen and Labourers of England, Scotland, and Ireland', 'To the Good and True Men of Hampshire, on the riotous proceedings at the Winchester Meeting,' 'To the Industrious Classes, on the Causes of the Present Poverty and Misery, 'To the Thinking People of England,' etc. These designations are of proto-classes, (at the moment of their 'making'), somewhere between a populist identification of the people as a whole, as against their rulers, and of one social class as against another.

The other took the form of open letters to his major adversaries, 'To Parson Malthus, on the Population of England,' 'To William Wilberforce, on the State of the Cotton Factory Labourers, and on the Speech of Andrew Ryding, who cut Horrocks with a cleaver,' to the Duke of Wellington, on the great good which will arise from his Measure relative to small notes', and even 'To the President of the United States.' 
(One recalls Bertrand Russell's Open Letters to Heads of State about the dangers of nuclear war as a later example of this genre).

In these addresses to public men, Cobbett responds to their Parliamentary speeches, or to their influential writings, constituting himself as a tribune of the people, answering what he regards as false and mischievous political positions. He often reports his opponents' positions and speeches at length, making a point of his willingness to let readers see both sides of an argument, whilst the authorities resort on their side to gagging and censorship. Cobbett, as Raymond Williams pointed out ${ }^{11}$, was a pioneer of the reporting of Parliamentary Debates. But this willingness to report his opponent's views does not make Cobbett polite about them:

\section{TO PARSON MALTHUS}

On the Rights of the poor and on the cruelty recommended by him to be exercised toward the poor. Political Register, May 1819

\section{PARSON,}

I have, during my life, detested many men; but never anyone so much as you. Your book on POPULATION contains matter more offensive to my feelings even than that of the Dungeon-Bill.It could have sprung from no mind not capable of dictating greater cruelty than any recorded in the history of the massacre of St Bartholomew. Priests have, in all age, been remarkable for cool and deliberate and unrelenting cruelty; but it seems to have been reserved for the Church of England to produce one who has a just claim to the atrocious pre-eminence. No assemblage of words can give an appropriate designation of you; and, therefore, as being the single word which best suits the character of such a man, I call you Parson, which, amongst other meanings, includes that of Boroughmonger tool....

In your book you show that, in certain cases, a crowded population has been attended with great evils, a great deal of unhappiness, misery, and human degradation. You then, without any reason to bear you out, predict, or leave it to be 
clearly inferred, that the same is likely to take place in England. Your principles are almost all false; and your reason, in almost any instance, is the same. But it is not my intention to waste time upon your abstract matter. I shall come, at once, to your practical result, to your recommendation to the Boroughmongers to pass laws to punish the poor for marrying....'

Cobbett quotes Malthus:

'... let us have your proposition before us in your own insolent words...'

"To this end I should propose a regulation to be made, declaring that no child born from any marriage taking place after the expiration of a year from the date of the law; and no illegitimate child born two years from the same date, should ever be entitled to parish assistance. After the public notice, which I have proposed, had been given, to the punishment of nature HE should be left; the punishment of severe want; all parish assistance should be rigidly denied him, HE should be taught that the laws of nature had doomed him and his family to starve; that HE had no claim on society for the smallest portion of food; that if HE and his family were saved from suffering the utmost extremities of hunger, HE would owe it to the pity of some kind benefactor, to whom HE ought to be bound by the strongest ties of gratitude."

Cobbett then proceeds to attack the unnaturalness of what Malthus advocates in the name of the laws of nature.

'You talk of the "punishment of nature;" you talk of "the laws of nature having doomed him and his family to starve." Now, in the first place, the laws of nature; the most imperative of her laws, bid him love and seek the gratification of that passion in the way that leads to the procreation of his species. The laws of nature bid man as well as woman desire to produce and preserve children. Your prohibition is in the face of these imperative laws; for you punish the illegitimate as well as the legitimate offspring...' 
Cobbett goes on to refute the idea that there had even been a large increase of population, since it was this belief that justified Malthus's attacks on poor relief and on all attempts to raise the living standards of the poor. Cobbett noted changes in statistical classifications, the apparent absurdity of the rate of growth reported, but he then typically asks his readers to look to the evidence of their own eyes to prove to themselves that Malthus must have been wrong. He points out that the size of the rural churches that everyone sees all around the country clearly shows that there must have been large congregations to fill them in the past:

'Then, if we take a look back, we shall find that in 1600 there could have been only about a couple of million of people in the country; that a couple of hundred years before there could have been no people at all in the country, or, only two or three pairs turned down as breeders, at any rate; and then, how the devil came the churches? They were built four hundred years before that; and will you, PARSON, undertake to make us believe that the churches were built without there being any body to go to them; that they were built, too, without hands.... '

Cobbett characteristically adds that even though there are supposed never to have been large congregations, nevertheless tithes are levied to support large benefices and livings for the clergy, like 'Parson Malthus.' The passage reads, and was probably written, as an speech in a imaginary debate with Malthus.

The assumption of such arguments as these is that opponents do have something to say which needs to be made known in its own terms, and then refuted. Incidentally, Thompson describes these kinds of writing as Cobbett's polemics, 'polemic' becoming one of Thompson's favourite terms. Another presupposition of this writing is that political debate essentially takes place between prominent individuals, who stand personally for social interests of various kinds. Cobbett had won the right to define himself in these terms as the representative of the popular interest, of the 'free born Englishman.' This is a political world in which influence is exercised by, and debate takes place between notables. Cobbett is writing at, and of course creating, that 
transitional moment at which it became possible to become such a notable by establishing oneself as a popular journalist or orator.

Thompson was drawn strongly himself to this role of the individual advocate and polemicist, attempting to embody in his political writings and speeches the voice of larger unheard publics. There sometimes seemed to be something anachronistic about this personalisation of political debate, which did not fit well with the modern world of organised party politics. Political parties spoke in slogans, in 'party lines', later in 'soundbites' attended by 'spin-doctors', not by reasoned argument and in individual polemics. Thompson denounced the hypocrisies of both orthodox Communist and Social Democratic parties, and the decadence of their debates. The first new left, and the nuclear disarmament campaign in its two phases, tried to construct an alternative public space in which such political arguments could be heard. But it was difficult for individuals, however eloquent and charismatic, or for loosely organised 'movements', to make a sustained impact on this political culture, or even to find an acknowledged space within it. How could someone like Edward Thompson conduct a public political argument with a Michael Stewart, or Fred Mulley, or John Nott, firstly when all the party apparatuses wanted to prevent such arguments taking place on public platforms, since it would endanger their own monopoly of political space, and secondly when many of the party functionaries in these roles could hardly begin to sustain such a level of debate in the first place. Thompson himself complained of this situation:

'These questions can't be asked in that set of frames. They aren't proper 'political' questions. This is partly because of the insufferable arrogance of the major political parties. Long ago they had the audacity, through parliamentary control of broadcasting, to confiscate this part of the nation's intellectual life to themselves. Politics was defined as party politics, and then it was carved up, unequally, between them.

If John Milton or William Hazlitt ${ }^{12}$ were still around, and wanted to break in a with a 
question of why or where, the managers of all the parties would gang up to keep them off. On every side a producer has to skirt around all these fenced-in estates with their party-political gamekeepers and notices saying 'PRIVATE TRESPASSERS KEEP OUT'. ${ }^{13}$

One of the attractions for Thompson of work with the dissenting movements of Eastern Europe, both in his earlier days as a dissident Communist, and later in the European peace movement, was that paradoxically in that authoritarian political context individual intellectuals and artists were able to have a more significant role as spokespersons for the people they were in the democratic west, where political communication is routinised and instrumentalised, as a form of public relations. ('New Labour' seems to be even more single-minded about this than Old Labour was). Dissenting politics in Eastern Europe transcended this pattern for a few years, but these nations now seem to have expelled their artists and intellectuals from political life, and to have defaulted to the professionalised party discourses of the Western type.

The first 'new left' attempted to create such a political space, and its failure was a damaging one so far as debate about democratic alternatives was concerned. A number of splits and divisions of political labour followed. Marxist militants found themselves confined mainly to sects, intellectuals were contained within the universities, and others who looked for more mainstream political had to struggle in the anaerobic atmosphere of the Labour Party. Thompson was comfortable with none of these roles, remaining remote from both party and sect. And having been involved in a vigorous campaign at Warwick University in $1970^{14}$ against the new managerialism of the 'business university,' (this concept really came into its own later on), he soon resigned from his academic post, preferring to work as an independent scholar. This liking for the role of a writer, polemicist, historian, and intellectual, over an institutional role, is something else which links Thompson to Cobbett.

However, the second great phase of the nuclear disarmament movement, and 
Thompson's involvement as the leading figure of E.N.D., the European Campaign for Nuclear Disarmament, did make it possible for him to find a significant public role. This phase brought a flow of political writings, two or three of which are classics ${ }^{15}$. Several of these pieces were constructed as arguments with representative public figures or intellectuals of the establishment. Thompson made a major contribution to the understanding of the nuclear arms race, developing the new theory of 'exterminism'. This was the idea of a reciprocally reinforcing military-industrial system, whose technical developments edge the world ever closer to final catastrophe. The idea of a 'mode of exterminism' was an important step in Thompson's continuing evolution away from economistic Marxism, since it attributed to the military systems of the two sides the capacity to drive their entire social systems. It was because these debates had some serious intellectual substance that Thompson's arguments with leading theorists of deterrence, like Sir Michael Howard, were conducted with overt respect on his side, if with devastating irony.

In Protest and Survive, the brilliant polemic occasioned by the government's civil defence pamphlet Protect and Survive, Thompson replies to a letter to The Times by Howard, which had advocated civil defence as necessary to the credibility of the nuclear deterrent:

'We are now at last prepared to cast a more realistic eye upon Professor Howard's scenario.

According to this, the 'initially limited Soviet strike' might, in the absence of civil defence precautions, create conditions of 'political turbulence' which would prevent 'us' from using our own nuclear weapons in retaliation. This would be regrettable, since it would inhibit the escalation from 'tactical' to 'theatre' to 'second strike', seabased nuclear war. But he envisages civil defence measures 'on a scale sufficient to give protection to a substantial number of the population', enabling this number to endure the 'disagreeable consequences' which would ensure.

The object of civil defence, then, is not so much to save lives as to reduce the 
potential for 'political turbulence' of those surviving the first strike, in order to enable 'us' to pass over to a second and more fearsome stage of nuclear warfare. It is Professor Howard's merit that he states this sequence honestly, as a realistic, and even that he allows that the consequences will be disagreeable.'

Thompson characterised the practical advice given by the government:

....The population of this country, however, will not be invited to these bunkers, and it is an Official Secret to say where they are. The population will be sent off, with a do-it-yourself booklet (Protect and Survive), to wait in their own homes. They will be advised to go down to the ground floor or the cellar, and make a cubby-hole there with old doors and planks, cover it sandbags, books, and heavy furniture, and then creep into these holes with food and water for fourteen days, a portable ratio, a portable latrine, and, of course, a tin-opener.'

Thompson notes, however, that the government has been cannier about the likely public response to preparations for major nuclear attacks than Howard himself. :

'I suspect that, for these reasons, Professor Howard is regarded, by publicrelations-conscious persons in the Establishment, as a great patriot of NATO and an admirable fellow, but as an inexperienced politician. The people of the country have been made dull and stupid by a diet of Official Information.But they are not all that stupid, and there is still a risk - a small risk, but not one worth taking - that they might remember who they are, and become 'turbulent' before the war even got started.' ${ }^{16}$

Thompson regarded the management of public opinion, by the use of Official Secrets legislation and the intimidation of dissidents as means of preparing populations for merely for nuclear deterrence, but for the possibility of nuclear war itself. He became concerned, as Cobbett had been during the French Wars, about the effects of military preparations and paranoia on civil liberties, and wrote vigorously about the secret state 
and its apparatus of spies and deceit, and about the individual victims of State intimidation and oppression.

In discussing apologists for the secret state, he was less polite than in his debate with the academic theorists of deterrence. His review of a book by Chapman Pincher, a journalist closely identified and linked with the intelligence agencies, was a polemical masterpiece. In it, Thompson produced a metaphorical flight equal to one of Cobbett's own. (Benjamin Disraeli, in Sybil, has one of his characters say of another "but he can write his mother tongue, as Shakespeare and Cobbett wrote it, and you must do that if you wish to influence the people." ${ }^{17}$ )

'Mr Chapman Pincher has been employed for over thirty years as a sort of common conduit through which government ministers, senior civil servants and others have leaked their official secrets, scandals and innuendoes to their readers and to each other. He has now published an account of this commerce, called Inside Story. I have examined this work, less with an eye to the subject-matter (mainly Westminster and Whitehall trivia) than to Mr Pincher's style of operation.'

The central figure of speech develops as the piece proceeds.

'...we may suppose that Mr Pincher has been less an operator than a tool of other operators. In this view, we must suppose that no one has leaked Official Secrets improperly. All the leaking has been contrived and wholly proper.lt has been an exercise of our superiors in the management of news; in which proper persons decide not only when an Official Secret becomes an Unsecret, but how it becomes an Unsecret for some, while it remains defended by criminal sanctions if published by others.

This might be justified as an exercise in confusing and 'disinforming' the KGB, although in fact, as in the case of Burghfield, the real objective is to confuse, disinform and manage opinion in Britain. 
In this view, the columns of the Express may be seen as a kind of official urinal in which, side by side, high officials of MI5 and MI6, Sea Lords, Permanent UnderSecretaries, Lord George Brown, Chiefs of the Air Staff, nuclear scientists, Lord Wigg, and others, stand patiently leaking in the public interest. One can only admire their resolute attention to these distasteful duties.'

The occasion for this piece was the Official Secrets Trial against Crispin Aubrey, John Berry and Duncan Campbell. Its serious point was to demonstrate that Pincher had published, with detailed information whose official sources he freely announces, and clearly with official sanction, classified materials which if they had been published by nuclear campaigners would have led to their trial and imprisonment. (Later, of course, Clive Ponting and Sarah Tindale were prosecuted, and the latter imprisoned. Such are the workings of the Secret State, Thompson showed.

One is reminded, in political substance, of Cobbett's defence of those harshly treated by the game laws, or in the repression of the Captain Swing disturbances, and of his vigorous denunciations of the tame press of the government. And in metaphorical form, of the wonderful passage, quoted in The Making of the English Working Class, in which Cobbett compares Brougham and the moderate reformers as scarecrows or Shoy-Hoys. He describes the homely functions of scarecrows in a field, and concludes:

'Just exactly such are the functions of our political shoy-hoys. The agricultural shoyhoys deceive the depredating birds but a very short time; but they continue to deceive those who stick them up and rely upon them, who, instead of rousing in the morning, and sallying upon the depredators with powder and shot, trust to the miserable shoy-hoys and thus lose their corn and their seeds. Just thus it is with the people, who are the dupes of all political shoy-hoys. In Suffolk, and other eastern counties, they call them mawkses.'

(quoted in The Making..., Penguin, P. 825). 
As Thompson argued and also demonstrated by example, it is possible to engage in and convey significant political thinking by means of metaphors whose power is their connection with readers' everyday experience.

Nevertheless, because of the difficulties of sustaining fundamental debate in the mainstream political arenas, the main objects of most of Thompson's great polemics were not his leading political contemporaries - grey figures for the most part by comparison with himself - but other political intellectuals of the left - Perry Anderson and Tom Nairn, Louis Althusser, Leslek Kolakowski - all figures marginal to the British political scene. In these polemics, Thompson achieved great heights of writing, combining wonderful and entertaining conceits and metaphors, with sustained theoretical arguments for a politics of self-activity guided by an understanding of the particularity of British history. He mocked, for example, Anderson and Nairn's negative view of British radical achievement:

'And the essence of both authors' analysis of Labourism may be found in Anderson's phrase, "In England, a supine bourgeoisie produced a subordinate proletariat."

.....There is about them, the air of an inverted Podsnappery.

"We Englishmen are Very Proud of our Constitution, Sir,", Mr Podsnap explained with a sense of meritorious proprietorship:

It was Bestowed Upon Us By Providence. No Other Country is as Favoured as This Country...'

"'And other countries, ' said the foreign gentleman. 'They do how?'

"'They do, Sir, ' returned Mr Podsnap, gravely shaking his head; 'they do - I am sorry to be obliged to say it - as they do.'

But now the roles are reversed. Mr Podsnap, who has swelled to engross all British 
culture over the past 400 years) is being arraigned in his turn.

" And other countries, " said Mr Podsnap remorsefully. "They do how."

"They do," returned Messrs Anderson and Nairn severely: "They do - we are sorry to be obliged to say it - in Every Respect Better. Their Bourgeois Revolutions have been Mature. Their Class Struggles have been Sanguinary and Unequivocal. Their Intelligentsia has been Autonomous and Integrated Vertically. Their Morphology has been Typologically Concrete. Their Proletariat has been Hegemonic."

There is indeed throughout their analysis an undisclosed model of Other Countries, whose typological symmetry offers a reproach to British exceptionalism. Set against this model, the English working class is "one of the enigmas of modern history,", the historical experience of the English bourgeoisie has been "fragmented, incomplete,", English intellectuals have not constituted "a true intelligentsia."'

\section{'The Peculiarities of the English,' in The Poverty of Theory, P. 36-7.}

This was however the 'specialisation' or narrowcasting of the kind of argument that Thompson would have liked to see going on in every pub. But modern mass politics and communications do not allow much complexity in political debate. It is salutary to think that in the 1820's Cobbett's Political Register had, by the standards of the time, a mass circulation - a 50,000 weekly sale in a population of eight or nine million.

Repeated reference to the self in such writing is not always easy to bring off, and Edward Thompson, even in the fine piece about official secrets quoted above did not succeed all the way through. Cobbett's peculiar gift for writing about himself, but with a constant sense that what really mattered was the objects of his attention and feeling, and not himself, is very hard to emulate. It is perhaps his completely open acknowledgement of his pride in himself which is so disarming ${ }^{18}$, at least in his public persona. (He is happy to tell his readers of how he was chaired in triumph 
from a public meeting, and can make an enjoyable anecdote of it). There is no false modesty, no self-regard which is not open to view. Perhaps it was the intensity of Cobbett's relationship to so many projects and activities - his farm, his journalism, his public rows, his meetings, his hates, his books - which successfully contained his extraordinarily powerful sense of self. (The collapse of Cobbett's marriage and his quarrels with his children in his last years perhaps show the price that others paid for the long years of support demanded by this energetic but egotistical man.) Cobbett's incredible volume of activity and writing reminds one in this respect of Charles Dickens, in the next generation.

Sometimes Thompson was able to integrate in his writing this eloquently personal voice, with an engagement with an external subject sufficiently intense to justify a highly personal authorial presence. The pieces in which this is brought off ${ }^{19}$ seem to come out of the possibility of a real collective engagement, in which Thompson can legitimately feel that he speaks for more than himself, even when he speaks as himself. But these conditions are not easy to fulfil in contemporary political practice, and there are other writings where the touch - that is the implied relationship with his subject and his audience - are less sure. ${ }^{20}$.

Cobbett seemed to have a confidence in his knowledge of those he wrote about - a knowledge no doubt continually replenished by his travels - which it is hard for contemporary socialists and radicals to keep hold of. Thompson wrote eloquently enough of his comrades in the socialist movement and later in the peace movement, but sometimes his wishes for the movement he would have liked to see took precedence over accurate perceptions of what actually existed. This 'movement' was sometimes there in experience, and sometimes wasn't, and Thompson's political writing at times reflects these uncertainties.

Both for Cobbett and himself, writing seems to work best when the relationship to the subject is most intense and grounded - in agricultural life, for Cobbett, and more often in his historical writing rather than politics, for Thompson. 
Thompson's historical and political writing plainly achieved the highest qualities of argument, evocation of experience, and theoretical subtlety. But it has another distinctive dimension too, which makes it quite unlike the work of most other historians and writers on politics. This can be understood in terms of the dimensions of the identity of the writer, and the identifications on which this is based. The past transmits itself to us in Thompson's writing not simply in what and who he writes about, but also in how he writes, and whose voices he remembers and recreates in doing so. Outstanding writers are perhaps most often formed by partial identification with their predecessors ${ }^{21}$, and this certainly seems to have been the case for Thompson.

This has a collective dimension, since his achievement in The Making of the English Working Class was to re-discover and re-create for contemporary readers and political actors the 'voices' of the early English working class movement. It is through such writing that collective traditions are remembered and enabled to continue in a living form, as Thompson so memorably explained:

'I am seeking to rescue the poor stockinger, the Luddite cropper, the 'obsolete' hand-loom weaver,the 'utopian' artisan, and even the deluded follower of Joanna Southcott, from the enormous condescension of posterity. '

The Making of the English Working Class, P.13.

But such identification also takes place at an individual level. It is through this process that the register and voice of a writer may be initially formed, and which can become a root of his or her subsequent imaginative work. I hope I have demonstrated that Cobbett was one key such figure for Edward Thompson. (William Morris and William Blake, the subject of major biographical works by 
Thompson, were two others, who shared with Cobbett the characteristic independence of mode of life and voice which Thompson achieved for himself.

One hopes that the models of political writing based in experience which Cobbett established, and Thompson re-created in his own work, will be emulated by new generations of writers, for the sake of the democratic practice to which both Cobbett and Thompson gave a full commitment.

\section{Works cited, by Edward Thompson}

The Making of the English Working Class, Penguin ed., 1968.

Whigs and Hunters, Allen Lane, 1975.

Customs in Common, Penguin, 1991.

Writing by Candlelight, Merlin Press, 1980

The Heavy Dancers, Merlin Press, 1985

The Poverty of Theory, Merlin Press, 1978

E.P. Thompson (ed), Warwick University Limited, Penguin, 1970.

E.P. Thompson and Dan Smith (ed) Protest and Survive, Penguin Special, 1980.

\section{Endnotes}

1. Republished in E.P.Thompson, Writing by Candlelight, Merlin, 1980.

2.. Cobbett is plainly aware of substantial differences of status and condition between himself and the labourers. Membership in a common moral community does not imply equality, for Cobbett. This is one important point of continuity between his earlier days as a Tory, which lasted until his return from North America in 1791, and direct experience of what the governing class was up to, and his subsequent thirty years as a Radical.

3.. See for example the Rural Ride for II October 1926, in which Cobbett writes: 'It is impossible to make men believe that any particular set of people should have a permanent property in wild creatures.'

4.. 'A large part was dictated - "dictated and not read - for he rarely looked over what he had written either when he put it down himself or when it was taken down by others.' (George Spater,

William Cobbett: the Poor Man's Friend, Vol. 1, Cambridge University Press, 1982, P.2. )

5.. Ian Dyck, William Cobbett and Rural Popular Culture, Cambridge University Press, 1992.

6.. George Spater reports an estimate of Cobbett's total written output as twenty million words.

7.. I have written elsewhere about Cobbett's pioneering of many forms of popular radical journalism. 
8.. Quoted in George Spater, op. cit., p. 372.

9.. As Thompson puts it, 'the personalisation of politics - this labourer in his cottage-garden, this speech in the House of Commons, that example of persecution - was well adapted to the pragmatic approach of an audience only awakening to political consciousness.' (Making, p. 829-830).

10.. Thompson's own role in the British new left in the late 1950s and early 1960s has been criticised for similar failings of over-personalisation. At a public level, these polemics could achieve a high level of eloquence and biting wit, and elicit responses of exemplary lucidity, as can be seen from Thompson's arguments with Perry Anderson and Tom Nairn, the second generation of editors of New Left Review, reprinted in

The Poverty of Theory, and from Anderson's reply in his Arguments within English Marxism (1980). See Michael Kenny, The First New Left, Lawrence and Wishart, 1995, for a thoughtful and well-researched account of this history.

11.. Raymond Williams, Cobbett, Oxford University Press, 1983.

12.. Hazlitt, of course, wrote one of the most judicious and balanced assessments of Cobbett, in The Spirit of the Age, Oxford University Press, 1960.

13.. The Heavy Dancers, Merlin Press, 1983, p. 3.

14.. E.P. Thompson (ed), Warwick University Limited, Penguin 1970.

15.. See Writing by Candlelight, Merlin Press, 1980; The Heavy Dancers, Merlin Press, 1985; E.P. Thompson and Dan Smith (ed) Protest and Survive, Penguin Special 1980.

16.. There is in Thompson's references here to the potentially turbulent people a hint of the way he inclined to selfdramatise the radical movements with which he identified. Even if dissent was not an overwhelming force, Thompson always needed to feel that it could become so. His sense of the real public he represented was nearly always more precarious and romanticised than Cobbett's relationship to his.

17.. Disraeli, B., Sybil, Bk. II chapter 16, p.171, Penguin Classics 1985.

18.. Thompson quotes Hazlitt on Cobbett, to this purpose:

'His egotism is delightful, for there is no affectation in it. He does not talk of himself for lack of something to write about, but because some circumstance that has happened to himself is the best possible illustration of the subject, and he is not the man to shrink from giving the best possible illustration of the subject from a squeamish delicacy. He likes both himself and the subject too well. He does not put himself before it, and say, 'Admire me first,' but places us in the same situation with himself, and makes us see all that he does..'

Making, P. 829.

19.. Examples are the polemics with Anderson, Nairn, and Althusser, the 'Highly Confidential Personal Comment' in Warwick University Limited, and Protest and Survive.

20.. An example is the 'Letter to Leslek Kolakowski' in The Poverty of Theory.

21.. The crucial, and in his view quasi-Oedipal, relation of major creative writers with their chosen predecessors is the theme of Harold Bloom's The Anxiety of Influence:a Theory of Poetry, Oxford University Press, 1973. 